\title{
Infectious and inflammatory mechanisms in preterm birth and cerebral palsy
}

\author{
Akademisk avhandling \\ som för avläggande av medicine doktorsexamen vid Göteborgs Universitet kommer \\ att offentligt försvaras i kvinnoklinikens aula, Sahlgrenska \\ Universitetssjukhuset/Östra fredagen den 16 maj klockan 13.00.
}

av

Bo Jacobsson

Legitimerad läkare

Avhandlingen är baserad på följande delarbeten:

I. Jacobsson B, Mattsby-Baltzer I, Holst RM, Andersch B, Bokstrom H, Wennerholm UB, Hagberg H. Microbial invasion and cytokine response in amniotic fluid in a Swedish population of women in preterm labor. Acta Obstet Gynecol Scand 2003;182(2):120-8

II. Jacobsson B, Mattsby-Baltzer I, Holst RM, Andersch B, Bokstrom H, Nikolaitchouk N, Wennerholm UB, Hagberg H. Microbial invasion and cytokine response in amniotic fluid in a Swedish population of women with preterm prelabor rupture of membranes. Acta Obstet Gynecol Scand 2003;In press.

III. Jacobsson B, Mattsby-Baltzer I, Holst RM, Nikolaitchouk N, Wennerholm UB, Hagberg H. Interleukin-18 in cervical and amniotic fluid: relationship to microbial invasion of the amniotic cavity, intra-amniotic inflammation and preterm delivery. Br J Obstet Gynaecol 2003; In press.

IV. Jacobsson B, Holst RM, Wennerholm UB, Andersson B, Lilja H, Hagberg H. Monocyte chemotactic protein-1 in cervical and amniotic fluid: relationship to microbial invasion of the amniotic cavity, intra-amniotic inflammation and preterm delivery. Am J Obstet Gynecol 2003; In press.

V. Jacobsson B, Hagberg G, Hagberg B, Ladfors L, Niklasson A, Hagberg H. Cerebral palsy in preterm infants: a population-based case-control study of antenatal and intrapartal risk factors. Acta Paediatr 2002;91(8):946-51.

Handledare:

Prof. Henrik Hagberg

Perinatalmedicinskt centrum

Institutionen för kvinnor och barns hälsa

Sahlgrenska Universitetssjukhuset/Östra

Göteborg
Bihandledare: Opponent:

Doc. Inger Mattsby-Baltzer Professor Roberto Romero

Doc. Ulla-Britt Wennerholm Perinatology Research Branch

Med.Dr. Lars Ladfors

National Institutes of Health

Bethesda, MD

USA 


\title{
Infectious and inflammatory mechanisms in preterm birth and cerebral palsy
}

by

\author{
Bo Jacobsson
}

Perinatal Center, Department of Obstetrics and Gynecology, Institute for the health of women and children, Sahlgrenska University Hospital/East, SE-416 85 Göteborg, Sweden.

bo.jacobsson@obgyn.gu.se

Background: International studies of women in preterm labor (PTL) and preterm pre-labor rupture of the membranes (pPROM) have shown a significant association between microbial invasion of the amniotic cavity (MIAC), some cytokines and chemokines and preterm birth (PTB). These studies have been performed in countries with higher incidence of PTB than that in Sweden. Cerebral palsy (CP) has also been shown to be associated with infectious and inflammatory mechanisms in international epidemiological studies. Our aim was to examine the role of inflammatory mechanisms in PTB and $\mathrm{CP}$ in a setting with a low incidence of PTB and perinatal infections.

Material and Methods: Amniotic fluid (AF) was retrieved transabdominally from 61 patients in PTL and 47 patients with pPROM, before 34 weeks of gestation in both groups. Forty-five women at term ( $\geq 37$ weeks) were included. These women were scheduled for elective cesarean section after uncomplicated pregnancies. Cervical fluid was obtained from the external cervical os in all patients in PTL and in all term patients. Polymerase chain reaction analyses for Ureaplasma urealyticum and Mycoplasma hominis and culture for aerobic and anaerobic bacteria were performed. Interleukin (IL)6, IL-8, IL-18 and monocyte chemotactic protein (MCP)-1 were analyzed with enzyme-linked immunosorbent assay.

In order to examine inflammatory mechanisms in $\mathrm{CP}$, a population-based series of 148 preterm infants with spastic CP, born 1983-90, were included and matched with a control group $(n=296)$. Subgroup analyses of patients with spastic diplegia and hemiplegia and those born at $<32$ and $\geq 32$ weeks were performed. Maternal, antenatal and intrapartal variables were retrieved from obstetric records.

Results: MIAC was detected in $16 \%$ of women in PTL and $25 \%$ of women with pPROM. Patients in PTL with MIAC had significantly elevated levels of IL-6, IL-8 and IL-18. The levels of IL-6, IL-8 and MCP-1 were elevated in MIAC cases in women with pPROM. There was also a significant association between elevated levels of IL-6, IL-8, IL-18 and MCP-1 and short amniocentesis-delivery interval $(\leq 7$ days) and PTB ( $<34$ weeks) in women in PTL, whereas this association was less evident in women with pPROM. A receiver-operator-characteristic curve was used to identify the best cut-off levels of IL-6 and IL-8 in AF for delivery within 7 days. This value was used to define an inflammatory response. The inflammatory response rate was $46 \%$ in the PTL group and $51 \%$ in the pPROM group. Elevated IL-18 and MCP-1 were related to an inflammatory response in the women in PTL; MCP-1 was also related to an inflammatory response in women with pPROM. There were higher levels of IL18 and MCP-1 in the cervical fluid of women in PTL, compared with non-laboring women at term. There were elevated levels of MCP-1 in the cervical fluid of women in PTL who gave birth within 7 days or before 34 weeks of gestation, who had MIAC or had intra-amniotic inflammation.

In the case-control study of CP, clinical chorioamnionitis/pyelonephritis, long interval between rupture of membranes and birth and admission-delivery interval $<4$ hours just significantly increased the risk of CP. Apgar scores of $<7$ at 5 and 10 minutes were strongly associated with an increased CP risk. Abruptio placentae and pathological non-stress test (reason for delivery) were significant risk factors for CP only in the moderately preterm and hemiplegic groups, whereas fever prior to delivery was a significant risk factor in the very preterm and spastic diplegic groups.

Conclusion: The occurrence of intra-amniotic microbial invasion and inflammation in this population of Swedish women in PTL and pPROM was similar to that reported in data from populations with a higher incidence of PTB. In addition, our data support an association between antenatal infection/inflammation and CP.

Keywords: preterm birth, preterm labor, preterm prelabor rupture of membranes, intra-uterine infection, intra-amniotic inflammation, interleukin-6, interleukin-8, interleukin-18, monocyte chemotactic protein-1, cerebral palsy, antenatal risk factors, chorioamnionitis.

ISBN 91-628-5711-8 